\title{
Desafios da produção e da comunicação científica em saúde no Brasil
}

A produção científica no Brasil cresce com velocidade em praticamente todas as áreas do conhecimento. Segundo o Diretório dos Grupos de Pesquisa do CNPq, há atualmente 48.871 pesquisadores cadastrados no país, reunidos em 11.760 grupos de pesquisa e atuando em 224 instituições.

$\mathrm{Na}$ área da saúde, boa parte desse crescimento está associado à expansão e consolidação da pós-graduação. Em 2000, aproximadamente 30\% dos grupos de pesquisa filiavam-se às áreas das ciências da saúde e/ou biológicas. Segundo Reinaldo Guimarães, esse conjunto de grupos informou ao Diretório cerca de 9.000 linhas de pesquisa, o que mostra que constituem campos bastante proeminentes da pesquisa no país (Rev. Saúde Pública, 35:321-340, 2001).

Tomando como referência a biblioteca eletrônica SciELO, os indicadores também apontam para o predomínio das áreas da saúde e biomédicas. De um total de quase 100 títulos de periódicos atualmente disponíveis na SciELO, cerca de metade estão relacionados a essas áreas. As duas revistas com o maior número de acessos plenos a artigos (downloads) são Cadernos de Saúde Pública e Revista de Saúde Pública, que já ultrapassaram a marca dos 300 mil hits.

Ao mesmo tempo em que evidenciam o nível de maturidade e de produtividade da pesquisa em saúde no Brasil, esses dados também apontam para os crescentes desafios a serem enfrentados pelos profissionais de ciência da informação e editores científicos. $\mathrm{O}$ mosaico de desigualdades que caracteriza o país permeia também a disseminação da informação e da comunicação científica. Há não somente desigualdades no acesso aos financiamentos necessários à geração de conhecimento, como também no acesso à informação atualizada, conseqüentemente trazendo impactos sobre a produção científica.

Aproximadamente $80 \%$ dos grupos de pesquisa estão situados no Sul-Sudeste. A região Nordeste totaliza $14,5 \%$ e a Norte apenas $2,7 \%$. Os resultados dessas desigualdades são perversos e se retroalimentam, sendo visíveis nos indicadores de produção. Em análise de 60 cursos de pós-graduação em todas as áreas nos anos 90, Maria das Graças Targino demonstrou o grau do desequilíbrio inter-regional existente. De um total de 2.780 artigos, $55 \%$ foram publicados por pesquisadores do Sul-Sudeste, com uma média de 9,9 artigos por docente. A produção cadastrada nas regiões Norte-Nordeste totalizou 912 artigos, com 4,5 artigos por docente. Na área da epidemiologia, Reinaldo Guimarães e colaboradores delineiam um panorama semelhante. Apesar de se tratar de campo de investigação estratégico para o país, em 2000, cerca de $80 \%$ de um total de 176 grupos de pesquisa em Epidemiologia encontravam-se no Sul-Sudeste. A região Norte, na qual predominam endemias de grande magnitude, contava com apenas 5 grupos. Outro indicativo da concentração é que as parcerias são majoritariamente Norte-Sul, existindo poucas redes de pesquisadores nos eixos Nordeste-Nordeste, Norte-Norte ou Nordeste-Norte.

Tudo isso poderia ser explicado com base em uma aritmética simples: mais pesquisadores e mais doutores, como no Sul-Sudeste, também mais produção. Porém, esse raciocínio incorre no risco de "naturalizar" as desigualdades, desconsiderando importantes determinantes históricos, políticos e sociais de nossa Academia. Não há indícios de que o cenário esteja mudando na escala necessária para reverter o complexo quadro de desigualdades existentes. Como em outras dimensões das políticas públicas no Brasil, um desafio importante na área da ciência e da tecnologia, incluindo a produção e a comunicação científica, é reduzir a concentração e aumentar o acesso dos grupos e instituições às condições necessárias para uma mais efetiva produção do conhecimento.

Carlos E. A. Coimbra Jr.

Editor 


\section{Challenges for scientific output and communications in health in Brazil}

Scientific output has grown rapidly in Brazil in practically all fields of knowledge. According to the Research Group Directory of the National Research Council (CNPq), there are currently some 48,871 registered researchers in the country working in a total of 11,760 research groups and 224 institutions.

In the field of health, a major portion of the growth is associated with the expansion and consolidation of graduate studies programs. In 2000, approximately $30 \%$ of all Brazilian research groups belonged to the health and/or life sciences fields. According to Reinaldo Guimarães, this set of groups had reported some 9,000 lines of research to the Directory, demonstrating that they represent highly prominent research fields in the country (Rev. Saúde Pública, 35:321-340, 2001).

Taking the SciELO electronic library as the reference, the indicators confirm the predominance of the health and biomedical fields. Approximately one-half of the nearly 100 periodical titles currently available on SciELO are from these two related fields. The two journals with the most full-text downloads, with over 300 thousand hits to date, are Cadernos de Saúde Pública/Reports in Public Health and Revista de Saúde Pública. While these data reflect the level of maturity and productivity in health research in Brazil, they also highlight the growing challenges for information science professionals and scientific editors. The mosaic of inequalities characterizing Brazil as a whole also permeates the dissemination of information and scientific communications. There are inequalities not only in access to the necessary financing for generating knowledge, but also in access to up-todate information, with a resulting impact on scientific output.

Approximately $80 \%$ of Brazil's research groups are located in the South and Southeast. The Northeast region includes $14.5 \%$ and the North only $2.7 \%$ of the total. These perverse inequalities have a harmful feedback and are visible in output indicators. In an analysis of 60 graduate studies courses in all scientific fields in the 1990s, Maria das Graças Targino demonstrated this prevailing degree of heavy regional imbalance. Out of a total of 2,780 articles, $55 \%$ were published by researchers from the South and Southeast, with a mean of 9.9 articles per faculty member. Scientific output from the North and Northeast totaled 912 articles ( 4.5 articles per faculty member). In the field of epidemiology, Reinaldo Guimarães and collaborators face a similar scenario. Although epidemiology is a strategic research field for Brazil, in 2000 some $80 \%$ of a total of 176 groups in the field were located in the South and Southeast. In the North, where large-scale endemics predominate, there were only 5 research groups in epidemiology. Another indicator of this concentration is that the research partnerships are established primarily along a North-South axis, with few Northeast-to-Northeast, North-to-North, or Northeast-to-North research networks.

This situation could be explained by simple arithmetic: with more researchers and PhDs in the South and Southeast, nothing more natural than to see more scientific output there. Yet this kind of reasoning runs the risk of taking inequalities for granted, overlooking other historical, political, and social determinants in Brazilian science. There is no indication that this scenario is changing on the scale needed to produce a turnaround in the complex range of existing inequalities. As with other characteristics of public policy in Brazil, an important challenge in the field of science and technology (including scientific output and communications) is to reduce this concentration and increase access by groups and institutions in order to achieve the necessary conditions for the production of knowledge.

Carlos E. A. Coimbra Jr.

Editor 